\title{
In Vitro Evaluation of Some Bacterial Isolates as Biofertilizers and Biocontrol Agents Against The Second Stage Juveniles of Meloidogyne incognita
}

\author{
M. E. El-Hadad, M. I. Mustafa, Sh. M. Selim, A. E. A. \\ Mahgoob", T. S. El-Tayeb and Norhan H. Abdel Aziz ${ }^{\text {** }}$ \\ Department of Agricultural Microbiology; *Department of \\ Plant Protection, Faculty of Agriculture, Ain Shams, University, \\ Shoubra El-Kheima, Cairo and ${ }^{* *}$ Central Laboratory for \\ Agricultural Climate, Agricultural Research Center, Ministry of \\ Agriculture, Giza, Egypt.
}

\begin{abstract}
DEPRESENTATIVE soil samples were collected from the rhizosphere soils of different plant varieties grown in five Egyptian governorates. The soil samples were taken from areas where vegetable crops were moderately infected with nematodes causing galls on their root systems. The presence of plant parasitic nematodes (PPN) and free living nematodes (FLN) in the collected samples were estimated. In addition, one hundred and seventy six bacterial cultures which are well known as biofertilizers (some are able to fix nitrogen and the others solubilize either phosphate or potassium) were isolated. The isolated bacteria were screened based on their rate of growth. Thirty-five cultures of fast growing nitrogen fixing bacteria (NFB), phosphate solubilizing bacteria (PSB) and potassium solubilizing bacteria (KSB) and their cultural filtrates were tested in vitro as biocontrol agents against the second stage juvenile $\left(\mathrm{J}_{2 \mathrm{~s}}\right)$ of the Meloidogyne incognita. In general, higher mortality percentages of nematodes were recorded by bacterial cultures than their comparative cultural filtrates. The highest mortality levels $(100 \%)$ was recorded for cultures of NFB7, PSB2 and KSB2 at $10^{-1}$ dilution while it was $99.3,99.0$ and $97.8 \%$, respectively, at a dilution of $10^{-2}$. NFB7 exhibited a high nitrogen fixation rate $\left(4.2 \mu\right.$ mole $\left.\mathrm{N}_{2} / \mathrm{ml} / \mathrm{h}\right)$, while PSB2 and KSB2 revealed effective phosphate and potassium solubilization efficiencies compared with the control treatments (1.94 fold of available phosphate and 2.0 fold of available potassium, respectively). NFB7, PSB2 and KSB2 isolates showed the highest protease, gelatinase and chitinase activities, which might be responsible for their nematicidal effect. The three bacterial isolates were identified as Paenibacillus polymyxa, Bacillus megaterium and Bacillus circulans, respectively.
\end{abstract}

Keywords: Biofertilizers, Biocontrol, Root-knot nematodes, Meloidogyne incognita.

Root-knot nematodes, Meloidogyne spp., are considered to be one of the most economically-important plant parasites causing severe damage to a wide variety of

Contact authors e-mails: tarekeltayeb@yahoo.com,hmdmahgoob@yahoo.com 
crops. The use of chemical nematicides is one of the primary means for their control. However, the potential negative impact on the environment and ineffectiveness after prolonged use have led to a total ban or restricted use of most chemical nematicides and an urgent need for safe and more effective options (Zuckerman \& Ensard, 1994). Biological control promises to be such an option (Padgham \& Sikora, 2007). Application of microorganisms antagonistic to nematodes or compounds produced by these microbes could provide additional opportunity for managing the damage caused by root-knot nematodes. Such microorganisms can produce substances that may limit the damage caused by these nematodes, e.g. by producing antibiotics, siderophores and a variety of enzymes. These microorganisms can also function as competitors of nematodes for colonization sites and nutrients. Paenibacillus polymyxa, $B$. megaterium and B. circulans are common soil bacteria belonging to plant growth promoting rhizobacteria (PGPR). Activities associated with these bacteria include nitrogen fixation (Coelho et al., 2003), soil phosphorus solubilization (Jisha \& Alagawadi, 1996), solubilizing insoluble K (Sheng et al., 2002 and Hu et al., 2006), as well as promotion of increased soil porosity (Gouzou et al., 1993). P. polymyxa has been used for the biocontrol of plant diseases (Kharbanda et al., 1999). Besides, $P$. polymyxa produces antimicrobial substances active against fungi and bacteria (Wang \& Liu, 2008). Hong-bo et al. (2006) reported that silicate dissolving bacteria like $B$. circulans preferentially stimulate crop yields and increases potassium uptake.

The objective of this work was to isolate and purify bacteria from the soils and rhizosphere of vegetable crops growing in soils naturally infested with nematodes (Meloidogyne spp. and others). These bacteria have double purpose: 1- Can mobilize soil nutrients (nitrogen, phosphate and potassium). 2- Act as biocontrol agents against the second stage juvenile $\left(\mathrm{J}_{2 \mathrm{~s}}\right)$ of Meloidogyne incognita. Such findings will open the door to further investigations in order to monitor the beneficial double purpose of these bacteria in greenhouse experiments.

\section{Materials and Methods}

\section{Materials}

Soil used for isolation of bacteria and nematodes

Soil samples were collected randomly from the rhizosphere and soil apart of different vegetable crops which mostly shown minor gall formation, e.g. tomato (Lycopersicon esculentum Mill., cv. Castel Rock), eggplant (Solanum melongena var. esculenta), cucumber (Cucumis sativus var. sativus), squash (Cucurbita pepo var. Eskandrani) and okra (Abelmoschus esculentus L. Moench). These plants were grown in five different Egyptian governorates according to the following locations: Monufia, lower; Fayium, upper; Sharqia, upper; Beheira, lower and Qalyubia, lower. The Upper governorates are those located south of Cairo, while the Lower governorates are the ones located in the Delta of the Nile north of Cairo. The soil samples were taken from $20 \mathrm{~cm}$ depth using pre-sterilized plastic scoops then put into sterile plastic bags and stored in iceboxes during their transport to the laboratory. In the laboratory all samples were kept refrigerated until analysis. The rhizosphere and soil samples collected from each plant variety were thoroughly mixed to compose representative samples. These soil samples

Egypt. J. Microbiol. 45 (2010) 
were used for isolation of specific groups of bacteria (which well known as biofertilizers) and for extraction of soil nematodes.

\section{Microbiological media used}

Modified Buntt \& Rovira medium (Mahmoud et al., 1976) and modified Aleksandrov's medium (Zahra et al., 1984) were used for the detection of phosphate and potassium solubilizing bacteria, respectively. MBS medium (medium based on sucrose) (Mohamed, 2001) was used for isolation of nitrogen fixing bacteria. Tryptic soy agar medium (Wiwat et al., 1999), Skim milk agar medium and gelatin agar medium (Shumi et al., 2004) were used for the detection of chitinase, protease and gelatinase activities, respectively. ML medium (Mollica et al., 1985) was used to determine the acetylene reduction activity.

\section{Methods}

Isolation and identification of bacterial biofertilizers

Serial dilutions up to $10^{-7}$ of the collected soils and rhizosphere samples were prepared using sterilized water. Suitable dilutions of each soil sample were plated (in triplicates) on three different media, namely modified Buntt \& Rovira, modified Aleksandrov's and MBS which recommended to isolate the NFB, PSB and $\mathrm{KSB}$, respectively. After 4 days of incubation at $30^{\circ} \mathrm{C}$, colonies were picked up, purified, then maintained on nutrient agar at $4^{\circ} \mathrm{C}$. The identification of the most efficient bacterial isolates was carried out according to Paul et al. (2004) and by the Biolog MicroPlate test panel (Biolog, Inc., USA) (Gelman et al., 2000) at Cairo Microbiological Resources Center (Cairo Mircen), Faculty of Agriculture, Ain Shams University, Cairo, Egypt.

Selection of bacterial isolates according to their growth intensity

All the isolates were cultured separately in nutrient broth and incubated at $30^{\circ} \mathrm{C}$ for 2 days. The optical cell density was measured at $600 \mathrm{~nm}$ using spectral photometer (Unicum).

\section{Extraction and identification of nematodes}

The samples used for isolating bacteria, were at the same time used for the extraction of nematodes using the modified Baermann funnel technique (Southy, 1986). The estimated population size of nematodes was expressed as numbers per $\mathrm{kg}$ soil. Recognition and identification of PPN and FLN to the genera level were carried out in The Nematology and Acarology Research Center at Fac. Agric., Ain Shams Univ., Egypt according to Goodey \& Goodey (1963) and Nickle (1991).

Propagation of Meloidogyne spp. in pure culture

To obtain a pure culture of root-knot nematodes, roots infected with Meloidogyne spp. were carefully washed with a gentle flow of water to remove the adhering soil particles. A single egg mass was reared separately on tomato seedlings (Lycopersicon esculantium Mill cv. Castel Rock), which were cultivated in plastic pots $(20 \mathrm{~cm}$ diameter $)$ filled with a mixture of sterilized loamy-sand: clay $(1: 1 \mathrm{v} / \mathrm{v})$. Pots were kept under greenhouse conditions. They were watered daily with tap water and with a nutrient solution once a week. A

Egypt. J. Microbiol. 45 (2010) 
nematode inoculum second stage juveniles $\left(\mathrm{J}_{2 \mathrm{~s}}\right)$ was obtained from galled tomato roots that were washed thoroughly with tap water, cut into pieces and placed in mist chamber for egg hatching. The first catch was discarded, and then the following emerged $\mathrm{J}_{2 \mathrm{~s}}$ were collected daily and kept refrigerated at $6^{\circ} \mathrm{C}$ until used in the experiment.

\section{Identification of Meloidogyne sp.}

The identification of Meloidogyne sp. was determined by scanning electron microscope (SEM). The adult nematode females were fixed first in $2.5 \%$ glutaraldelyde for $24 \mathrm{hr}$ at $4^{\circ} \mathrm{C}$, followed by post-fixing in $1 \%$ osmium tetroxide for $1 \mathrm{hr}$ at room temperature. The females were dehydrated with ascending concentrations of acetone to the dried critical point, and finally spotted and coated with gold. The examination and photographing were done by using a JEOL Scanning Electron Microscope (JSM-T330A), as described by Harley $\&$ Ferguson (1990). The cuticle marking surrounding the vulva and anus (perineal pattern) of the females of the root-knot nematodes assisted the identification process (Taylor \& Nestscher, 1974).

\section{The bacterial-nematicidal activity test}

Propagation of bacterial isolates in shake flasks : Conical flasks $(250 \mathrm{ml})$ containing $100 \mathrm{ml}$ of nutrient broth medium were inoculated with each bacterial isolate, then incubated at $28-30^{\circ} \mathrm{C}$ for two days with shaking at $150 \mathrm{rpm}$. Serial dilutions of $10^{-1}-10^{-5}$ were prepared using sterile distilled water to test in vitro their correspondent nematicidal activity against the second stage juveniles $\left(\mathrm{J}_{2 \mathrm{~s}}\right)$ of M. incognita (Gordon, 1977).

Screening test of bacterial isolates against the second stage juveniles $\left(J_{2 s}\right)$ of $M$. incognita : To determine the efficiency of bacterial isolates against the $\mathbf{J}_{2 \mathrm{~s}}$ of $M$. incognita, sterilized $5 \mathrm{ml}$ porcelain cups were supplied with one $\mathrm{ml}$ of each dilution of either bacterial liquid cultures or culture filtrates $(1 \mathrm{ml}$ of original culture contained $2 \times 10^{7}$ viable cells) and one $\mathrm{ml}$ of nematode sterilized suspension (sterilized according to Kim \& Riggs, 1991) containing $250 \pm 50$ individuals of $\mathrm{J}_{2 \mathrm{~s}}$ per cup, and incubated at $28-30^{\circ} \mathrm{C}$ for $48 \mathrm{hr}$. Plain water in cups supplied with nematodes were used as a control. Cups were loosely covered by their own covers, which permitted aeration but reduced evaporation. Each dilution and the control were replicated three times. The numbers of individuals surviving and dead were counted after $48 \mathrm{hr}$ using a 1-ml nematode counting slide. Corrected mortality percentage was calculated according to Schneider \& Orelli (1947)

Assessment of some physiological activities of the selected bacterial isolates Nitrogenase and phosphatase activities : Nitrogenase activity of nitrogen fixing isolates was determined according to the method described by Hardy et al. (1973). To determine the phosphatase activity of the selected PSB isolates, a modified Buntt and Rovira liquid medium (Mahmoud et al., 1976) was inoculated with a loop of each active culture. After 4 days of incubation at $30^{\circ} \mathrm{C}$, phosphatase activity was determined according to the method of Jackson (1973).

Egypt. J. Microbiol. 45 (2010) 
Potassium solubilization : Nutrient broth medium was inoculated by a loop of each KSB active culture and incubated for $24 \mathrm{hr}$ at $30^{\circ} \mathrm{C}$. One millilitre of each culture was transferred to modified Aleksandrov's medium (Zahra et al., 1984) and incubated in a shaking incubator at $150 \mathrm{rpm}$ at $30^{\circ} \mathrm{C}$ for one week. Shaken cultures were used to determine soluble $\mathrm{K}$ using flame photometer (Share Wood) as described by Jackson (1973).

Protease, gelatinase and chitinase activities : A loop of active culture of each of the selected isolates was spotted on skim milk agar medium and gelatin agar medium for the detection of protease and gelatinase activities, respectively. Plates were incubated for $24 \mathrm{hr}$ at $30^{\circ} \mathrm{C}$. For chitinase activity, a loop of each isolate was spotted on tryptic soy agar medium containing colloidal chitin for 5 days at $30^{\circ} \mathrm{C}$. Colloidal chitin was prepared according to the method adopted by Roberts \& Selitrennikoff (1988). Activities of protease, gelatinase and chitinase enzymes were expressed by diameter zone of hydrolysis in $(\mathrm{cm})$.

\section{Statistical analysis}

The obtained data were statistically analyzed by using Statistical Analysis System (SAS 2000). Duncan`s Multiple Range Test was used to test significance between means according to Snedecor \& Cochran (1989).

\section{Results and Discussion}

\section{Isolation of bacterial biofertilizers}

A total number of 176 bacterial isolates were isolated from the rhizosphere and soil apart of tomato, eggplant, cucumber, squash and okra. Among these isolates, there were 39, 63 and 74 as NFB, PSB and KSB, respectively. These isolates were characterized as straight rods, Gram positive, motile cells. Ongoing tests showed that the variations among the efficient growing isolates as nematode biocontrol agents. The efficiency of these isolates as promising $N \quad \mathrm{P}$ biofertilizers was considered as well.

\section{Occurrence of nematodes associated with some vegetable crops}

The presence of PPN and FLN in the soil samples was estimated. Two genera of PPN were found and identified as Meloidogyne spp. and Pratylenchus spp. Four genera of FLN were found and identified as Dorylaimus spp., Rhabdities spp., Acropeles spp. and Cephalobus spp. (Table 1). Tomato, squash and eggplant were found to be infested by 63.6, 28.8 and $7.7 \%$ of PPN, respectively. Obviously, the root-knot nematode Meloidogyne spp., was the most dominant (93.61\%) among all the recorded PPN. However, 72.9, 18.2 and 3.15\% of FLN were associated with tomato, squash and eggplant, respectively. Sasser (1989) reported that the most widespread and economically important nematode species included in the root-knot nematodes were Meloidogyne sp., Rotylenculus sp. and Tylenculus sp. The host ranges of these nematodes include most, if not all, of the commercially grown vegetables and fruit crops within Egypt (ElHaddad et al., 2003). 


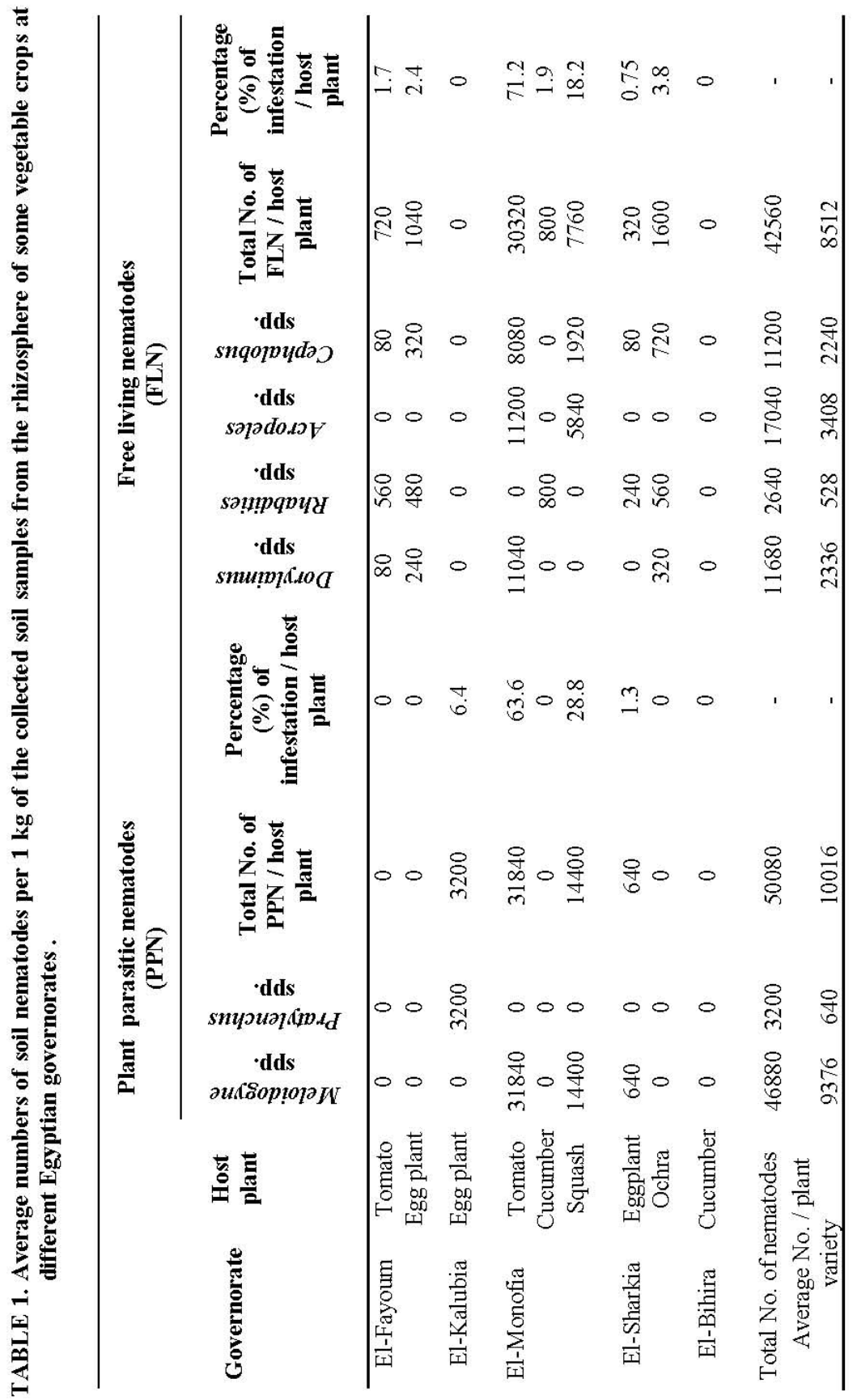


Identification of Meloidogyne sp.

The identification of Meloidogyne sp. was carried out by scanning electron microscope (SEM). The cuticle marking surrounding the vulva and anus (perineal pattern) of the mature females of the root-knot nematodes indicated that these nematodes are Meloidogyne incognita as seen in the following image:

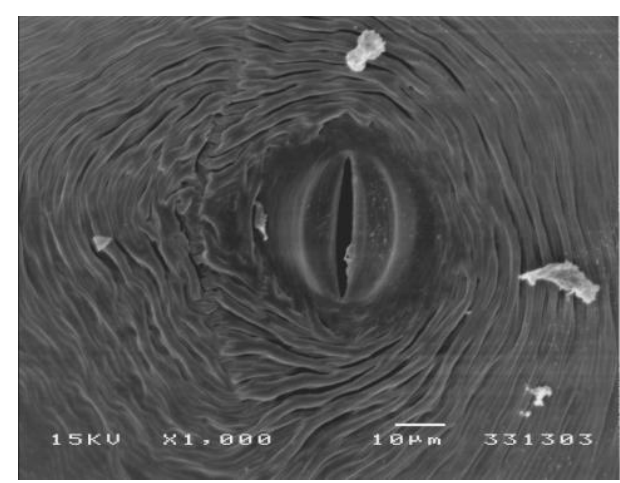

Selection of bacterial isolates

All bacterial isolates were screened depending on the intensity of their growth in liquid cultures. Optical density determinations indicated that only 35 isolates achieved the highest growth rate (ranged from 0.6 to 0.8 O.D). Of these, eight NFB, thirteen PSB and fourteen KSB were chosen for further studies.

Nematicidal effect of the selected NFB, PSB and KSB bacterial cultures against the second stage juveniles $\left(J_{2 s}\right)$ of $M$. incognita

Thirty five bacterial isolates (8 NFB, 13 PSB and 14 KSB) were tested against the $\mathrm{J}_{2 \mathrm{~s}}$ of $M$. incognita. Data given in Table 2 indicate that isolates NFB2, NFB5, NFB6 and NFB7 achieved the highest mortality percentages at dilutions of 1/10 (100\% mortality). The mortality percentage of NFB 7 at $1 / 100$ was the highest $(99.3 \%)$ compared with the other tested isolates, followed by isolates NFB5 and NFB2. There was no significant difference between NFB5 and NFB6 at a dilution 1/1000.

PSB isolates gave in general lower results as compared with those of NFB especially at dilutions $1 / 100$ and 1/1000. Among the PSB isolates, PSB2 achieved the highest significant mortality percentage (99\%) at 1/100 dilution, followed by PSB4. At dilution 1/1000, PSB2 isolate was still the best (achieved $28.1 \%$ mortality) followed by PSB4 and PSB5 as they exerted 21.1 and $19.6 \%$ mortality, respectively.

KSB isolates exhibited merely the same effects compared with those of NFB or PSB. No significant differences were observed among isolates treatments in dilution 1/10. Isolates KSB2, KSB7 and KSB4 achieved the highest mortality percentages at dilutions of 1/10 (100\% mortality). The mortality percentage of KSB2 at 1/100 was the highest comparing with the other tested KSB isolates, being $97.8 \%$. These results were supported by the findings of Carneiro et al. (1998) who mentioned that bacterial whole culture of B. thuringiensis and B. laterosporus killed freshly emerged $\mathrm{J}_{2 \mathrm{~s}}$ of $M$. javanica within 24 to $48 \mathrm{hr}$, whereas treatments with $B$. thuringiensis aizawai, $B$. 
thuringiensis morrisoni and $B$. circulans caused only immobilization. Terefe et al. (2009) found an aqueous suspension of B. firmus at $2.5 \%$ and $3 \%$ concentration caused $100 \%$ inhibition of mobility, $24 \mathrm{hr}$ after treatment. In view of the results of the present study, it could be concluded that the bacterial isolates, namely NFB2, NFB5, NFB6, NFB7, PSB2, PSB4, PSB5, KSB2, KSB4 and KSB7 resulted in the highest nematicidal effect against the $\mathrm{J}_{2 \mathrm{~s}}$ of $M$. incognita. Thus it was of interest to verify whether the effect is mainly due to the intact cells or due to the culture filtrate itself.

TABLE 2. Mortality percentage of $M$. incognita $\mathbf{J}_{2 \mathrm{~s}}$ as affected by different dilutions of NFB, PSB and KSB bacterial isolates after $48 \mathrm{hr}$ of exposure period.

\begin{tabular}{|c|c|c|c|c|}
\hline \multirow{2}{*}{$\begin{array}{c}\text { Bacterial } \\
\text { isolates }\end{array}$} & \multicolumn{4}{|c|}{ Dilutions of liquid cultures } \\
\hline & 1/10 & $\mathbf{1 / 1 0 0}$ & $\mathbf{1 / 1 0 0 0}$ & $1 / 10000$ \\
\hline NFB isolates & & & & \\
\hline NFB1 & $92.8^{\mathrm{b}}$ & $60.3^{\mathrm{t}}$ & $9.1^{\text {et }}$ & 0 \\
\hline NFB2 & $100^{\mathrm{a}}$ & $94.9^{c}$ & $9.2^{\mathrm{et}}$ & 0 \\
\hline NFB3 & $99^{\mathrm{a}}$ & $43^{g}$ & $27.2^{\mathrm{c}}$ & 0 \\
\hline NFB4 & $100^{\mathrm{a}}$ & $78.5^{\mathrm{e}}$ & $13.7^{\mathrm{d}}$ & 0 \\
\hline NFB5 & $100^{a}$ & $95.8^{\mathrm{bc}}$ & $37.8^{b}$ & 0 \\
\hline NFB6 & $100^{\mathrm{a}}$ & $84.9^{\mathrm{de}}$ & $36.5^{b}$ & 0 \\
\hline NFB7 & $100^{\mathrm{a}}$ & $99.3^{\mathrm{a}}$ & $45.9^{\mathrm{a}}$ & 0 \\
\hline NFB8 & $100^{\mathrm{a}}$ & $37.1^{\mathrm{g}}$ & $8.5^{\mathrm{f}}$ & 0 \\
\hline PSB isolates & & & & \\
\hline PSB1 & $100^{\mathrm{a}}$ & $33.6^{t}$ & $11.8^{\mathrm{e}}$ & $2^{b}$ \\
\hline PSB2 & $100^{\mathrm{a}}$ & $99^{a}$ & $28.1^{\mathrm{a}}$ & 0 \\
\hline PSB3 & $100^{\mathrm{a}}$ & $43.2^{\mathrm{e}}$ & $8.8^{\mathrm{e}}$ & 0 \\
\hline PSB4 & $100^{a}$ & $80.4^{b}$ & $21.1^{b c}$ & 0 \\
\hline PSB5 & $100^{\mathrm{a}}$ & $48.2^{\mathrm{d}}$ & $19.6^{\mathrm{cd}}$ & 0 \\
\hline PSB6 & $100^{a}$ & $42.2^{\mathrm{e}}$ & $0.5^{f}$ & 0 \\
\hline PSB7 & $98.7^{a b}$ & $28.3^{g}$ & $0.7^{1}$ & 0 \\
\hline PSB8 & $96.6^{c}$ & $52.7^{d}$ & $18.5^{\mathrm{d}}$ & 0 \\
\hline PSB9 & $93.6^{\mathrm{d}}$ & $26.6^{g}$ & 0 & 0 \\
\hline PSB10 & $93.7^{d}$ & $27.9^{g}$ & 0 & 0 \\
\hline PSB11 & $54.2^{\mathrm{e}}$ & $38.7^{\mathrm{e}}$ & $21.2^{b}$ & $20.4^{\mathrm{a}}$ \\
\hline PSB12 & $97.8^{\mathrm{bc}}$ & $67.8^{c}$ & $18.5^{\mathrm{d}}$ & 0 \\
\hline PSB13 & $100^{a}$ & $11.6^{\mathrm{h}}$ & 0 & 0 \\
\hline KSB isolates & & & & \\
\hline KSB1 & $100^{a}$ & $79.7^{\mathrm{d}}$ & $29.2^{b}$ & 0 \\
\hline KSB2 & $100^{\mathrm{a}}$ & $97.8^{\mathrm{a}}$ & $40.3^{\mathrm{a}}$ & 0 \\
\hline KSB3 & $100^{\mathrm{a}}$ & $42.6^{h}$ & $0.73^{\mathrm{g}}$ & 0 \\
\hline KSB4 & $100^{a}$ & $86.2^{c}$ & $18.8^{\mathrm{cd}}$ & 0 \\
\hline KSB5 & $100^{a}$ & $79.3^{d}$ & 0 & 0 \\
\hline KSB6 & $99.5^{\mathrm{a}}$ & $43.7^{h}$ & 0 & 0 \\
\hline KSB7 & $100^{\mathrm{a}}$ & $91.8^{b}$ & $10.3^{\mathrm{e}}$ & 0 \\
\hline KSB8 & $98.5^{\mathrm{a}}$ & $69.17^{\mathrm{e}}$ & $5.6^{1}$ & 0 \\
\hline KSB9 & $100^{a}$ & $23.3^{\mathrm{J}}$ & $7.04^{1}$ & 0 \\
\hline KSB10 & $94.7^{\mathrm{ab}}$ & $50.8^{g}$ & $16.5^{\mathrm{d}}$ & 0 \\
\hline KSB11 & $100^{a}$ & $33.4^{1}$ & $5.5^{1}$ & 0 \\
\hline KSB12 & $100^{a}$ & $60.2^{1}$ & $35.9^{\mathrm{a}}$ & 0 \\
\hline KSB13 & $100^{a}$ & $62.7^{1}$ & $20.9^{c}$ & 0 \\
\hline KSB14 & $100^{a}$ & $17.9^{\mathrm{J}}$ & $7.6^{1}$ & 0 \\
\hline
\end{tabular}

* Means not followed by the same letter are significantly different by Duncan`s multiple range test $(\mathrm{P}>0.05)$.

Egypt. J. Microbiol. 45 (2010) 
Nematicidal effect of the selected bacterial cultures filtrates of NFB, PSB and $K S B$ against the $J_{2 s}$ of $M$. incognita

Ten isolates of the three categories of bacterial isolates obtained from previous experiment that achieved the highest levels of nematicidal activity were further examined as cultural filtrates with different dilutions. As shown in Table 3 , bacterial culture filtrates of NFB7, PSB2 and KSB2 recorded the highest mortality percentages of $J_{2 s}$. In general, the filtrates of all bacterial cultures were dramatically less effective on nematode mortality as compared with their whole bacterial cultures (Table 2). The presence of bacterial cells was then recommended to achieve high mortality percentages. Ali et al. (2002) found that culture filtrates of Pseudomonas sp. produced juvenile mortality of $M$. javanica. Khan et al. (2008) reported that exposure of $M$. incognita to various concentrations $(5-100 \%)$ of culture filtrate of Paenibacillus polymyxa under in vitro conditions significantly reduced egg hatch and caused substantial mortality of its juveniles.

TABLE 3. Mortality percentage of $M$. incognita $\mathrm{J}_{2 \mathrm{~s}}$ as affected by different dilutions of NFB, PSB and KSB cultures filtrates after $48 \mathrm{hr}$ of exposure period .

\begin{tabular}{|c|c|c|}
\hline \multirow{2}{*}{ Bacterial isolates } & \multicolumn{2}{|c|}{ Dilutions of culture filtrates } \\
\cline { 2 - 3 } & $\mathbf{1 / 1 0}$ & $\mathbf{1 / 1 0 0}$ \\
\hline NFB2 & $45.2^{\mathrm{b}}$ & $5.8^{\mathrm{b}}$ \\
\hline NFB5 & $36.3^{\text {cd }}$ & $9.2^{\mathrm{b}}$ \\
\hline NFB6 & $30.5^{\mathrm{d}}$ & 0 \\
\hline NFB7 & $62.5^{\mathrm{a}}$ & $19.7^{\mathrm{a}}$ \\
\hline PSB2 & $67.7^{\mathrm{a}}$ & $23.6^{\mathrm{a}}$ \\
\hline PSB4 & $20^{\mathrm{b}}$ & $1.5^{\mathrm{b}}$ \\
\hline PSB5 & $17^{\mathrm{b}}$ & $0.8^{\mathrm{c}}$ \\
\hline KSB2 & $47.8^{\mathrm{a}}$ & $17.2^{\mathrm{a}}$ \\
\hline KSB4 & $14.6^{\mathrm{c}}$ & 0 \\
\hline KSB7 & $25.7^{\mathrm{d}}$ & 0 \\
\hline
\end{tabular}

* Means not followed by the same letter are significantly different by Duncan`s multiple range test $(\mathrm{P}>0.05)$.

\section{Efficacy of the selected bacterial isolates as biofertilizers}

The same thirty five bacterial isolates were tested for their abilities to act as biofertilizers. NFB isolates were tested for their nitrogenase activity, while PSB and KSB isolates were tested for phosphate solubilization and potassium solubilization capacities, respectively.

\section{Nitrogenase activity}

Records of nitrogenase activity of eight NFB isolates are given in Fig. 1. NFB7 isolate achieved the highest level of nitrogenase activity $(4.2 \mu \mathrm{mole} / \mathrm{ml} / \mathrm{h})$ followed by NFB2 and NFB5 (3.39 and $3.33 \mu \mathrm{mole} / \mathrm{ml} / \mathrm{h}$, respectively). 


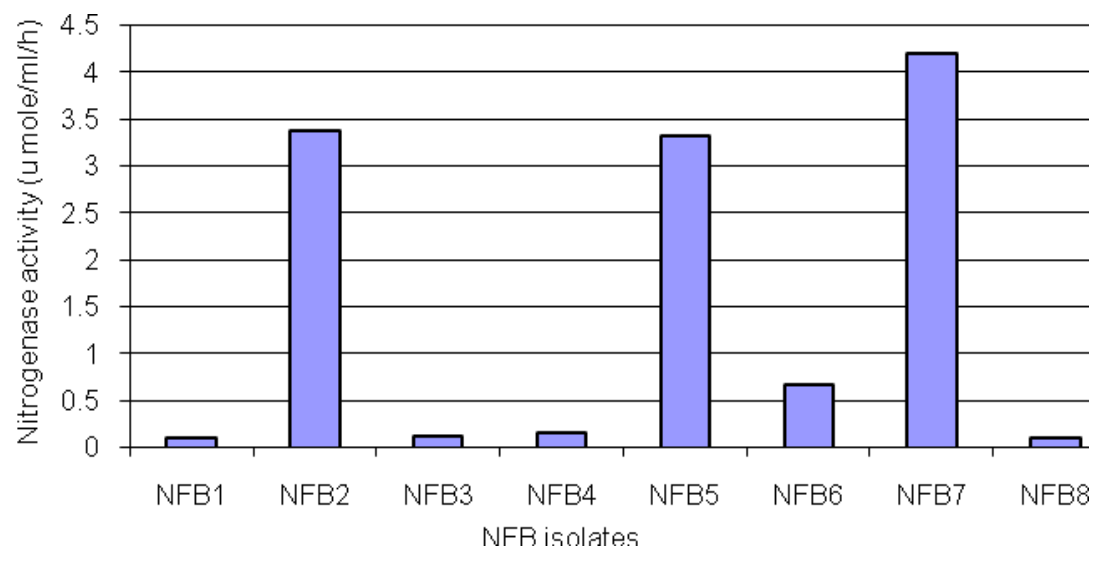

Fig. 1. Nitrogenase activity of NFB isolates grown in liquid ML medium (Mollica et al., 1985) after $48 \mathrm{hr}$ of incubation.

Phosphate solubilization efficiency

Thirteen PSB isolates were tested for their abilities to solubilize phosphate in liquid medium (Fig. 2). Isolate PSB2 achieved the highest level of solubilization (77.6 ppm of available phosphate) followed by isolate PSB7 (77.3 ppm of available phosphate). This amount of available phosphate was 1.94 fold greater than that in the control treatment. Han \& Lee (2005) recorded promising in vitro results and believed that solubilization of phosphatic compounds by naturally abundant PSB is very common under in vitro conditions.

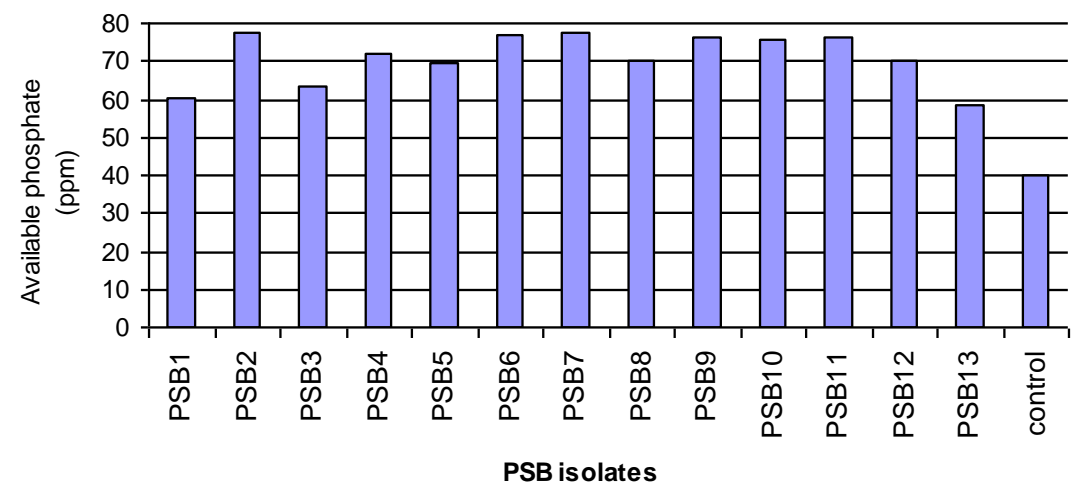

Fig. 2. Phosphate solubilization by PSB isolates grown in modified Bunt \& Rovira liquid medium (Mahmoud et al., 1976) after $72 \mathrm{hr}$ of incubation. 
Potassium solubilization efficiency

Fourteen KSB isolates were tested to solubilize insoluble potassium by growing in Aleksandrov's liquid medium containing mica as sole source of insoluble potassium. Data in Fig. 3 show that the KSB2 isolate achieved the highest potassium solubilization activity (15.48 ppm of available potassium), followed by KSB4 isolate (15.44 ppm of available potassium). This amount was 2 fold of the available potassium present in the control treatment.

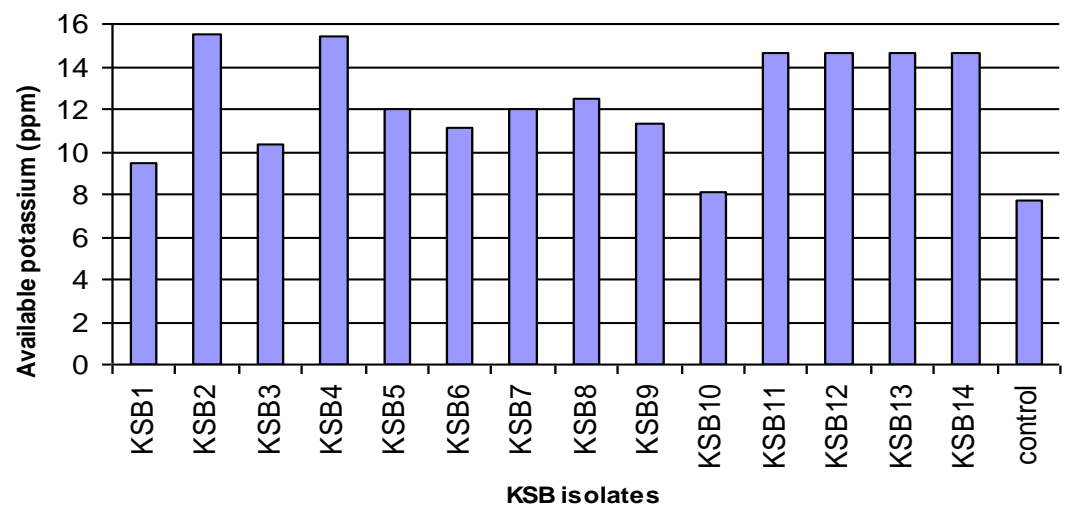

Fig. 3. Potassium solubilization by KSB isolates grown in modified Aleksandrov's liquid medium (Zahra et al., 1984) after 4 days of incubation.

\section{Abilities of the selected bacterial isolates for enzymes secretion}

Eight NFB isolates were tested for their protease, chitinase and gelatinase activities, which might help to explain how the bacteria could act against the rootknot nematodes. Results revealed that isolate NFB7 showed the highest protease, chitinase and gelatinase activities, being 7.0, 3.14 and $3.4 \mathrm{~cm}$, respectively (Fig. 4). The other NFB isolates produced less enzymes as compared with NFB7 isolate. In the case of PSB isolates, thirteen isolates were found to produce the three aforementioned enzymes. PSB2 recorded the highest enzymatic activity, being 3.9, 0.9 and $0.46 \mathrm{~cm}$ for protease, chitinase and gelatinase, respectively (Fig. 4). Testing KSB isolates for their enzymatic activity showed that KSB2 isolate was the best in this concern. It produced the highest levels of protease, chitinase and gelatinase activity, being 3.6, 0.9 and $0.91 \mathrm{~cm}$, respectively (Fig. 4).

It should be stated that the highest nematicidal activity exhibited by NFB7, PSB2 and KSB2 against $\mathrm{J}_{2 \mathrm{~s}}$ of $M$. incognita may be related to their high enzymes secretion abilities. Such consideration is in agreement with studies reported by De Jin et al. (2005) who evaluated chitinolytic bacteria as potential biocontrol agents of the root-knot nematode, $M$. incognita, on tomato. Their results indicated the potential of chitinase producing bacteria to alleviate nematode parasitism in important vegetable crops. 

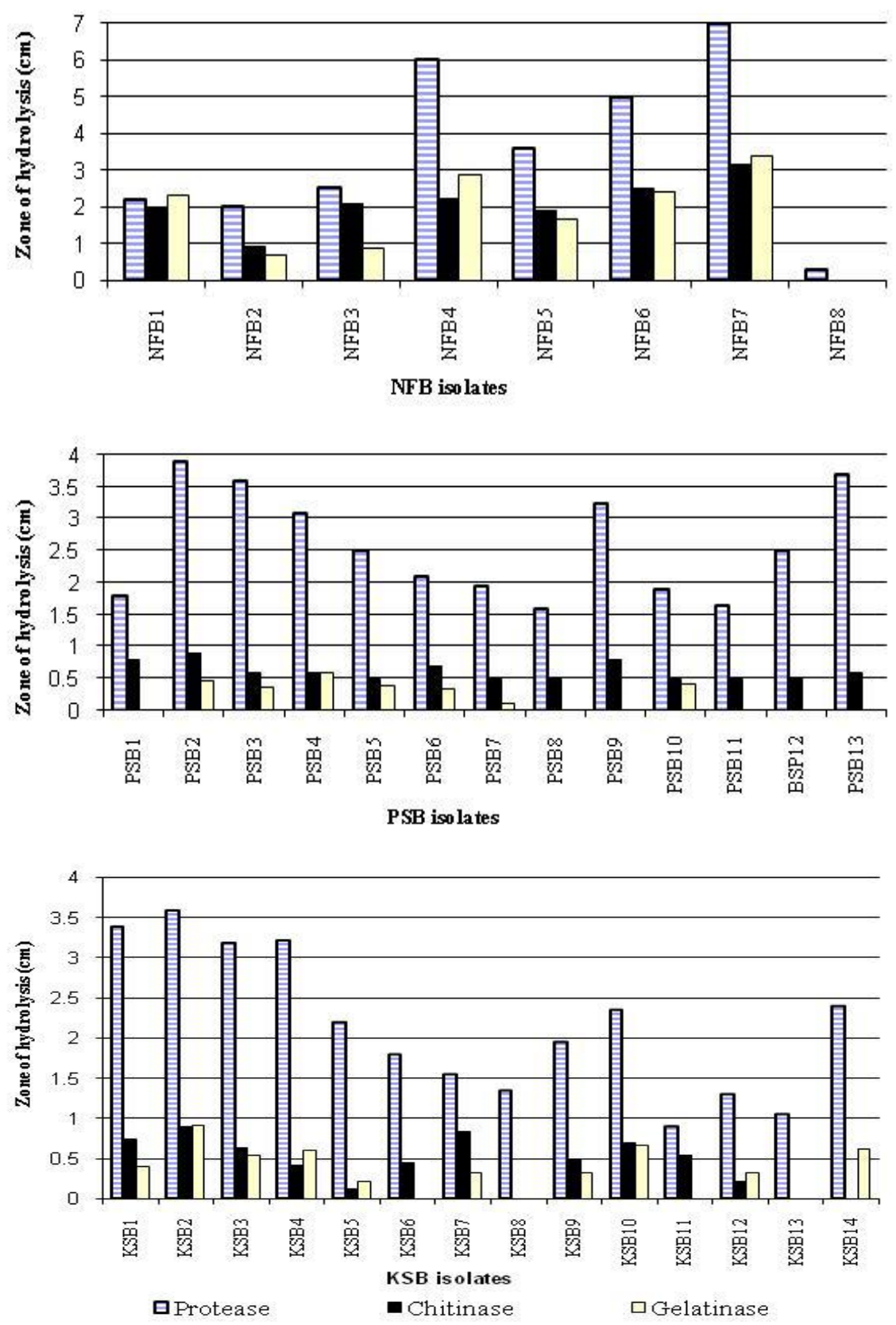

Fig. 4. Enzyme activity as expressed by zone of hydrolysis in (cm) of NFB, PSB and KSB isolates after $72 \mathrm{hr}$ of incubation on different media. 
Identification of the most efficient bacterial isolates

The NFB7, PSB2 and KSB2 isolates found to be the most efficient for use as biofertilizers and nematicidal agents were studied for their morphological and physiological characteristics. These results showed that they belong to Paenibacillus polymyxa, Bacillus megaterium and Bacillus circulans, respectively.

\section{Conclusions}

Paenibacillus polymyxa (NFB7), Bacillus megaterium (PSB2) and Bacillus circulans (KSB2) were found to be efficient biofertilizers and also have the ability to act against root-knot nematodes. The microbial activities of these isolates, if occurring in the rhizosphere of infested plants, will be implicated in the reduction of deleterious and pathogenic rhizosphere nematodes, thereby creating an environment more favorable for root growth. Accordingly, these efficient bacterial strains will be chosen to study their performance as biofertilizers and biocontrol agents under greenhouse condition in future work.

\section{References}

Ali, N.I., Siddiqui, I.A., Shaukat, S.S. and Zaki, M.J. (2002) Nematicidal activity of some strains of Pseudomonas spp. Soil Biol. Biochem. 34, 1051-1058.

Carneiro, R.M.D.G., Souza, I.S. and Belarmino, L.C. (1998) Nematicidal activity of Bacillus spp. strains on juveniles of Meloidogyne javanica. Nematol. Brasileira, 22, $12-21$.

Coelho, M. R. R., von der Weid, I., Zahner, V. and Seldin, L. (2003) Characterization of nitrogen-fixing Paenibacillus species by polymerase chain reaction-restriction fragment length polymorphism analysis of part of genes encoding 16S rRNA and 23S rRNA and by multilocus enzyme electrophoresis. FEMS Microbiol. Lett. 222, 243250.

De Jin, R., Won Suh, J., Dong Park, R., Woong Kim, Y., Krishnan, H.B. and Kim, K. (2005) Effect of chitin compost and broth on biological control of Meloidogyne incognita on tomato (Lycopersicon esculentum Mill.) Nematol. 7, 125-132.

El-Haddad, S.A., Omar, M.N. and El-Kattan, M.H. (2003) Comparative studies on some components of integrated management on soil borne plant pathogens affecting cucumber, grown under protected agriculture. International Symposium on: The Horizons of Using Organic Matter and Substrates in Horticulture. Acta Hort. (ISHS) 608,219-226 http://www.actahort.org/books/608/608_27.htm (accessed 18.10.2008).

Gelman, A., Drabkin, V. and Glatman, L. (2000) Evaluation of lactic acid bacteria isolated from lightly preserved fish products, as starter cultures for new fish-based food products. Innov. Food Sci. Emerg. Technol. 1, 219-226.

Goodey, T. and Goodey, J.B. (1963) "Soil and Freshwater Nematodes". London, Methuen and Co. Ltd. 544. p. 
Gordon, R.E. (1977) The genus Bacillus. In : "CRC Handbook of Microbiology”, vol. I, Laskin, A. L. Lechevalier, A. (Ed.). pp. 319-336. Cleveland, Ohio, USA, CRC Press. Inc.

Gouzou, L., Burtin, G., Philippy, R., Bartoli, F. and Heulin, T. (1993) Effect of inoculation with Bacillus polymyxa on soil aggregation in the wheat rhizosphere: preliminary examination. Geoderma, 56, 479-491.

Han, H.S. and Lee, K.D. (2005) Phosphate and potassium solubilizing bacterial effect on mineral uptake, soil availability and growth of eggplant. Res. J. Agric. Biol. Sci. 1, 176-80.

Hardy, R.W.F., Burns, R.C. and Holsten, R.D. (1973) Applications of the acetylene assay for measurement of nitrogen fixation. Soil Biol. Biochem. 5, 47-51.

Harley, M.M. and Ferguson, I.K. (1990) The role of the SEM in pollen morphology and plant systematics. In : "Scanning Electron Microscope in Taxonomy and Functional Morphology”. D. Claugher (Ed.). pp. 45-68. Systematics Association Special Vol. 41. Oxford, Clarendon Press.

Hong-bo, Z., Xiao-Xi, Z., Fei-fei, I., Guan-zhou, Q. and Yue-hua, H. (2006) Screening, identification; desilication of a silicate bacterium. J. Cent. South Univ. Technol. 13, 337-341.

Hu, X., Chen, J. and Guo, J. (2006) Two phosphate and potassium-solubilizing bacteria isolated from Tianmu mountain, Zhejiang, China. World J. Microbiol. Biotechnol. 22, 983-990.

Jackson, M.L. (1973) "Soil Chemical Analysis". $2^{\text {nd }}$ ed. Prentice Hall of India Private Limited, New Delhi, India.

Jisha, M.S. and Alagawadi, A.R. (1996) Nutrient uptake and yield of sorghum (Sorghum bicolor L. Moench) inoculated with phosphate solubilizing bacteria and cellulolytic fungus in a cotton stalk amended vertisol. Microbiol. Res. 151, 213-217.

Khan, Z.. Kim, S.G., Jeon, Y.H., Khan, H.U., Son, S.H. and Kim, Y.H. (2008) A plant growth promoting rhizobacterium, Paenibacillus polymyxa strain GBR-1, suppresses root-knot nematode. Bioresour. Technol. 99, 3016-3023.

Kharbanda, P.D., Yang, J., Beatty, P., Jensen, S. and Tewari, J.P. (1999) Biocontrol of Leptosphaeria maculans and other pathogens of canola with Paenibacillus polymyxa PKB1. In: Proceeding of $10^{\text {th }}$ International Rapeseed Congress. Canberra, Australia.http://www.digital.library.adelaide.edu.au/dspace/bitstream/2440/.../02whole. pdf (accessed 20.5.2009).

Kim, D.G. and Riggs, R.D. (1991) Characteristics and efficacy of a sterile hyphomycete (ARF 18), a new biocontrol agent for Heterodera glycines and other nematodes. J. Nematol. 23, 275-282.

Mahmoud, S.A.Z., Abdel-Hafez, A.M., EI-Sawy, M. and Hanafy, E.A. (1976) Efficiency of phosphate mobilizing bacteria on different phosphorus substrates in clay loamy soil. Egypt. J. Soil. Sci. 16, 9-20.

Egypt. J. Microbiol. 45 (2010) 
Mohamed, A.A. (2001) Studies on some asymbiotic $\mathrm{N}_{2}$ fixing bacterium. M. Sc. Thesis, Fac. Agric., Ain Shams Univ., Cairo, Egypt.

Mollica, M.L., van Elsas, J.D. and Elisa, G.C.P. (1985) An improved method to detect acetylene-reducing activity in Bacillus strains. J. Microbiol. Meth. 3, 147-157.

Nickle, W.R. (1991) “Manual of Agricultural Nematology”. pp. 191-274.Marcel Dekker, Inc. New York, Basel, Hong Kong.

Padgham, J.L. and Sikora, R.A. (2007) Biological control potential and modes of action of Bacillus megaterium against Meloidogyne graminicola on rice. Crop Prot. 26, 971 977.

Paul, D.V., George, M.G., Dorothy, J., Fred, A.R., Karl-Heinz, S. and William, B.W. (2004) In. "Bergey's Manual of Systematic Bacteriology". Vol.3, $2^{\text {nd }}$ ed., The Firmicutes, de Vos, Ed. pp.1203-1259. Springer-Verlag, New York.

Roberts, W.K. and Selitrennikoff, C.P. (1988) Plant and bacterial chitinases in antifungal activity. J. Gen. Microbiol. 134, 169-176.

SAS, (2000) "Statistical Analysis System", SAS User's Guide Statistics. SAS Institute Inc., Editor, Cary, NC, USA.

Sasser, J.N. (1989) Plant parasitic nematodes: the farmers hidden enemy. A cooperative publication of the Department of Plant Pathology and Consortium for International Crop Protection, p. 115.

Schneider, P. and Orelli, O. (1947) “Entomologisches Praktikum”. Aarau Verlag. H. R. Sauerländer Co. p. 237.

Sheng, X.F., He, L.Y. and Huang, W.Y. (2002) The conditions of releasing potassium by a silicate dissolving bacterial strain NBT. Agric. Sci. China. 1, 662-666.

Shumi, W., Hossain, M.T. and Anwar, M.M. (2004) Proteolytic activity of a bacterial isolates Bacillus fastidiosus den Dooren de Jong. J. Biol. Sci. 4, 370-374.

Snedecor, G.W. and Cochran, W.G. (1989) "Statistical Methods" $8^{\text {th }}$ ed., pp. 158-160. Iowa State Univ. Press, Ames, USA,

Southy, J.F. (1986) Laboratory methods for work with plant and soil nematodes. Ministry of Agriculture, "Fisheries and Food". $6^{\text {th }}$ ed. Ref. Book 402, p. 202. London. Her Majesty's Stationery Office.

Taylor, D.P. and Netscher, C. (1974) An improved technique for preparing perineal pattern of Meloidogyne spp. Nematol. 20, 268-269.

Terefe, M., Tefera, T. and Sakhuja, P.K. (2009) Effect of a formulation of Bacillus firmus on root-knot nematode Meloidogyne incognita infestation and the growth of tomato plants in the greenhouse and nursery. J. Invertebr. Pathol. 100, 94-99.

Wang, Z. and Liu, X. (2008) Medium optimization for antifungal active substances production from a newly isolated Paenibacillus sp. using response surface methodology. Bioresour. Technol. 99, 8245-8251.

Egypt. J. Microbiol. 45 (2010) 
Wiwat, C., Siwayaprahm, P. and Bhumiratana, A. (1999) Purification and characterization of chitinase from Bacillus circulans No.4.1. Curr. Microbiol. 39, 134140.

Zahra, M.K., Monib, M., Abdel-Al, S.H.I. and Heggo, A. (1984) Significance of soil inoculation with silicate bacteria. Zbl. Mikrobiol. 139, 349 - 357.

Zuckerman, B.M. and Esnard, J. (1994) Biological control of plant nematodes current status and hypothesis. Jpn. J. Nematol. 24, 1-13.

(Received 13/12/2009;

accepted $17 / 4 / 2010$ )

Egypt. J. Microbiol. 45 (2010) 


\section{التقييم المعملى لبعض العزلات البكتيرية كمسمدات حيوية وكعوامل مقاومة حيوية ضد لبفية الطور اليرقى الثانى لنيماتودا Meloidogyne incognita}

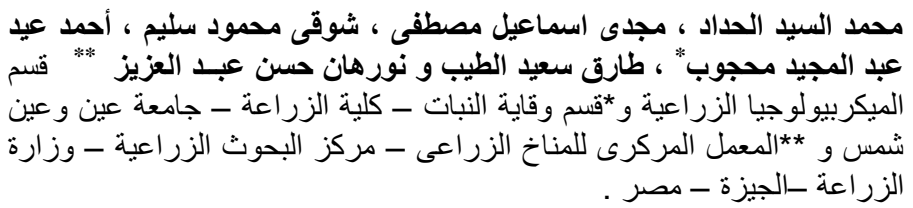

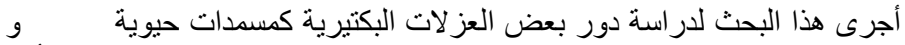

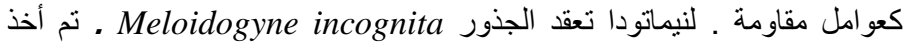

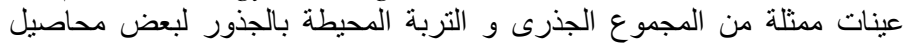

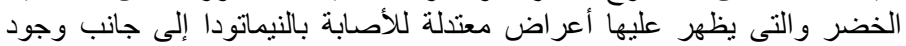

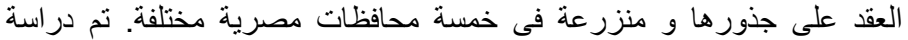

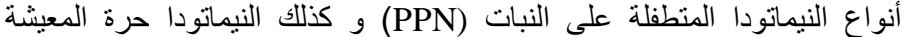

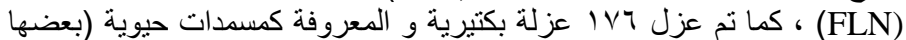

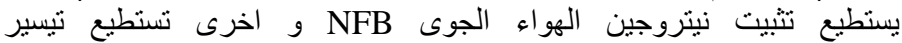
الفوسفات PSB ، فى حين للبعض الآخر القدرة على تيسير البوتاسيوم KSB)

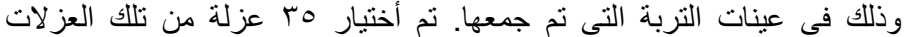

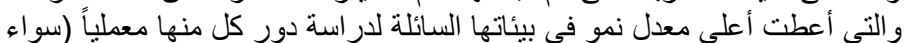

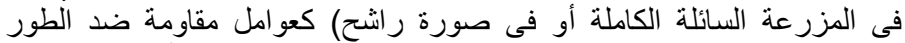

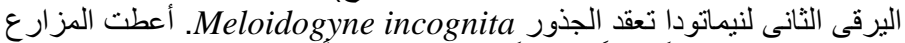

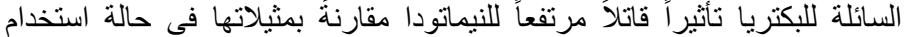

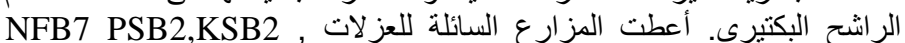

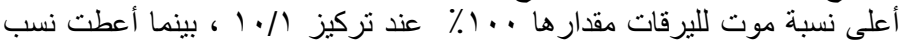
r, NFB7 نيتزوجين/مل/ساعة) ، بينما أظهرت العزبه

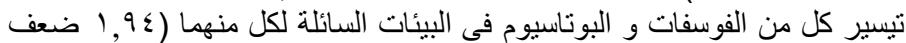

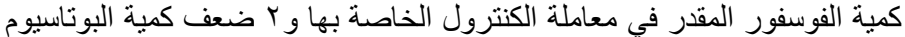

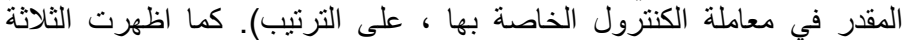

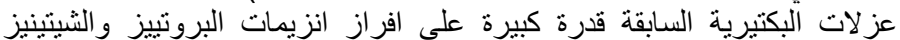

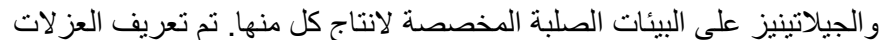
NFB7, PSB2, KSB2

Bacillus megaterium (PSB2), Paenibacillus polymyxa (NFB7)g Bacillus circulans (KSB2) 